Bangladesh J. Sci. Ind. Res. 41(1-2), 47-54, 2006

\title{
Fatty Acid Composition of Three Marine Fishes of the Bay of Bengal
}

\author{
Habibur R. Bhuiyan, K. K. Nath, P. Seal and Mir Ezharul Hossain \\ BCSIR Laboratories, Chittagong, Bangladesh.
}

\begin{abstract}
Oil samples collected from three fishes namely Sting Ray (Dasyatis uarrnak), Anchovy (Setipinna taty), and Eel (Congresox talabonoides) from the Bay of Bengal were analyzed to determine their fatty acid composition with the aid of Gas Liquid Chromatography (GLC). The saturated fatty acid contents were 52.95, 45.28 and $52.29 \%$; and the unsaturated fatty acid contents were 43.97, 54.72 and $33.39 \%$ in $D$. uarnak, S. taty and C. talabonoides respectively. The highest polyunsaturated fatty acid content was found in S. taty (13.65 \%) and the lowest was in D. uarnak (8.06 \%). The $\omega$-3 fatty acid contents were $4.58,3.65$ and $9.91 \%$ and the $\omega-6$ fatty acid contents were 3.48, 10.00 and $5.50 \%$ in D. uarnak. S. taty and C. talabonoides respectively. Two essential fatty acid linoleic acid (4.12 \%) and arachidonic acid (5.32 \%) contents were found higher in $S$. taty whereas another essential fatty acid linolenic acid (8.98 \%) found higher in C. talabonoides. Another important polyunsaturated fatty acid eicosapentaenoic acid (2.12\%) found higher in D. uarnak.
\end{abstract}

\section{Introduction}

Bangladesh is blessed with diversified aquatic wealth including fatty fishes in the Bay of Bengal. Several research reports stated that this area is rich in plankton, shrimps and commercial fishes. ${ }^{1}$ From FAO species survey report; it was known that 475 species of fish belonging to 138 families existed in this water. ${ }^{2}$ The present population growth (2.2\%) will require the total fish supply to increase by about 300,000 Mt. annually just to matntain the current lavel of average per capita fish consumption, which results over fishing of commercially important fish species. ${ }^{3}$ Fish is important not only for its protein but also for its oil. Marine fish oil is rich in vitamin $\mathrm{A}$ and $\mathrm{D}$ and polyunsaturated fatty acid especially $\omega$-3 fatty acid having properties of lowering blood pressure and cholesterol and thus preventing cardiovascular and renal diseases. ${ }^{4}$ Marine fish oil is also important for its essential fatty acid required for normal metabolic function. Marine fish oil is superior to fresh water oil and vegetable oil due to its higher content of 
polyunsaturated fatty acid especially $\mathrm{C}_{20}$ and $\mathrm{C}_{22}$ series and is received increasing attention in recent time. ${ }^{5,6}$

There are few reports on fatty acid composition of less and/or unutilized marine fishes like ray fish, flat fish, shark, eel, etc. in the Bay of Bengal. This report will increase the information of fatty acid composition of oils of the three marine fishes namely Sting Ray (Dasyatis uarnak), Anchovy (Setipinna taty) and Eel (Congresox talabonoides) as well as their nutritional value and commercial importance for better utilization of these three species.

\section{Materials and Methods}

\section{Raw materials collection}

The fish species of the Bay of Bengal were collected from fishery ghat, Chittagong.

\section{Fat extraction}

The fish oil samples were extracted from Sting Ray (D. uarnak) liver, Eel (C. talabonoides) body muscle and Anchovy ( $S$. taty) body muscle by solvent extraction method. ${ }^{2,5}$

\section{Saponification and esterfication}

Oil samples were then saponified with methanolic potassium hydroxide and with hexane and evaporated to dryness. ${ }^{4}$ The dried saponified materials were esterified with benzoic acid and boron-trifluoride methanol complex and extracted with hexane and concentrated to a suitable volume. ${ }^{4}$

\section{Standard}

Standard methyl esters of fatty acids were procured from E. Mark and Sigma in dry condition in ampoules. The ampoules were broken and methyl esters were dissolved in petroleum ether. The mixture containing methyl esters of 11 fatty acids namely Caprylic $\left(\mathrm{C}_{8: 0}\right)$, Capric $\left(\mathrm{C}_{10: 0}\right)$, Lauric $\left(\mathrm{C}_{12: 0}\right)$, Myristic $\left(\mathrm{C}_{14: 0}\right)$, Palmitoleic $\left(\mathrm{C}_{16: 1}\right)$, Stearic $\left(\mathrm{C}_{18: 0}\right)$, Oleic $\left(\mathrm{C}_{18: 1}\right)$, Linolenic $\left(\mathrm{C}_{18: 3}\right)$, Linoleic $\left(\mathrm{C}_{18: 2}\right)$, Arachidic $\left(\mathrm{C}_{20: 0}\right)$ and Behenic $\left(\mathrm{C}_{22: 0}\right)$ acids were used as standard for Gas Liquid Chromatography. ${ }^{4}$

Fatty acid \% was calculated as peak area/total area x 100 and peak area was height $\mathrm{x}$ width at the half height. ${ }^{4}$

\section{Results and Discussion}

Qualitative and quantitative information about the fatty acid composition of three fish oils (oil contents were 20.25, 0.51 and $9.56 \%$ in D. uarnak liver, C. talabonoides and $S$. taty body muscle respectively ${ }^{5}$ ) have been obtained from GLC. Although the pattern of fatty acid are almost similar in three fish oils, only the major difference is in the relative proportion of the individual fatty acid present.

Although 50 to 60 fatty acid could be identified by modern technology, but only four 
pairs of fatty acid namely $\mathrm{C}_{14: 0}+\mathrm{C}_{18: 0}$, $\mathrm{C}_{16: 1}+\mathrm{C}_{18: 1}, \mathrm{C}_{20: 1}+\mathrm{C}_{22: 1}, \mathrm{C}_{22: 5 \omega 3}+\mathrm{C}_{22: 6 \omega 3}$ which cover $80 \%$ to $85 \%$ are important. ${ }^{7}$ The content of individual fatty acid can be varied with the variation pf species and among the same species due to the variation of sex, season, feeding, salinity and temperarure. ${ }^{4,7}$

In the present investigation, the major and important fatty acids in Sting Ray
(D. uarnak) liver oil were palmitic (35.61 \%), oleic (24.71\%), stearic (9.72\%), palmitoleic (9.10 \%) and myristic (4.38 \%) acids (TableI). $\mathrm{Jahan}^{8}$ found that hilsa oil contained 31.35 $\% \mathrm{C}_{16: 0}, 15.91 \% \mathrm{C}_{18: 1} 22.39 \% \mathrm{C}_{18: 3}$ and 9.66 $\% \mathrm{C}_{18: 0}$. Yusuf et al $^{10}$ reported that hilsa oil contained $27 \% \mathrm{C}_{16: 0}, 18.7 \% \mathrm{C}_{16: 1}, 9.4 \%$ $\mathrm{C}_{18: 0}, 23 \% \mathrm{C}_{18: 0}, 23 \% \mathrm{C}_{18: 1}, 0.3 \% \mathrm{C}_{18: 3}$, slightly different values were observed with the present study due to the variation of

Table I. Fatty acid composition of Sting Ray liver oil (oil content $20.25 \%$ w/w $\mathbf{w}^{5}$ )

\begin{tabular}{|c|c|c|c|c|c|c|}
\hline \multirow[t]{4}{*}{ Name of the fatty acid } & \multirow{4}{*}{ Peak area } & \multicolumn{5}{|c|}{ Fatty acid (FA) \% } \\
\hline & & \multirow{3}{*}{$\begin{array}{c}\text { Saturated } \\
\text { FA } \\
\text { (SFA) }\end{array}$} & \multicolumn{3}{|c|}{ Unsaturated fatty acid (UFA) } & \multirow{3}{*}{ Unknown } \\
\hline & & & \multirow{2}{*}{$\begin{array}{c}\text { Mono } \\
\text { UFA }\end{array}$} & \multicolumn{2}{|c|}{ Poly UFA (PUFA) } & \\
\hline & & & & $\omega$-3 PUFA & $\omega-6$ PUFA & \\
\hline Caprylic $\left(\mathrm{C}_{8: 0}\right)$ & - & - & - & - & - & - \\
\hline Capric $\left(\mathrm{C}_{10: 0}\right)$ & 1549 & 3.24 & - & - & - & - \\
\hline Lauric $\left(\mathrm{C}_{12: 0}\right)$ & - & - & - & - & - & - \\
\hline Myristic $\left(\mathrm{C}_{14: 0}\right)$ & 2092 & 4.38 & - & - & - & - \\
\hline Myristoleic $\left(\mathrm{C}_{14: 1}\right)$ & 1003 & - & 2.10 & - & - & - \\
\hline Palmitic $\left(\mathrm{C}_{16: 0}\right)$ & 17020 & 35.61 & - & - & - & - \\
\hline Palmitoleic $\left(\mathrm{C}_{16: 1}\right)$ & 4349 & - & 9.10 & - & - & - \\
\hline Unknown & 1474 & - & - & - & - & 3.08 \\
\hline Stearic $\left(\mathrm{C}_{18: 0}\right)$ & 4644 & 9.72 & - & - & - & - \\
\hline Oleic $\left(\mathrm{C}_{18: 1}\right)$ & 11811 & - & 24.71 & - & & - \\
\hline Linoleic $\left(\mathrm{C}_{18: 2 \omega 6}\right)$ & 588 & - & - & - & 1.23 & - \\
\hline Linolenic $\left(\mathrm{C}_{18: 3 \omega 3}\right)$ & 1178 & - & - & 2.46 & - & - \\
\hline Arachidonic $\left(\mathrm{C}_{20: 4 \omega 6}\right)$ & 1074 & - & - & - & 2.25 & - \\
\hline Eicosapentaenoic $\left(\mathrm{C}_{20: 5 \omega 3}\right)$ & 1013 & - & - & 2.12 & - & - \\
\hline Docosapentaenoic $\left(\mathrm{C}_{22: 5 \omega 6}\right)$ & - & - & - & - & - & - \\
\hline \multirow[t]{4}{*}{ Total } & \multirow[t]{4}{*}{47795} & \multirow[t]{3}{*}{52.95} & \multirow[t]{2}{*}{35.91} & 4.58 & 3.48 & \multirow[t]{3}{*}{3.08} \\
\hline & & & & \multicolumn{2}{|c|}{8.06} & \\
\hline & & & \multicolumn{3}{|c|}{43.97} & \\
\hline & & \multicolumn{5}{|c|}{100.00} \\
\hline$\omega-3 / \omega-6=1.32$ & \multicolumn{3}{|c|}{ PUFA $/$ SFA $=0.15$} & \multicolumn{2}{|c|}{ UFA $/ \mathrm{SFA}=0.83$} & \\
\hline
\end{tabular}


species habitat, season, sex, spawning condition and feeding behavior etc. ${ }^{4,7}$

In Anchovy (S. taty), palmitic (31.92 \%), oleic (29.36\%), stearic (7.10\%), palmitoleic (11.03\%), myristic (5.26\%), linoleic (4.12 $\%)$ and arachidonic (5.32 \%) acids were major and important fatty acids (Table II). Chowdhury et. $a l^{4}$ found that shark liver oil contained $27.51 \%$ palmitic acid $\left(\mathrm{C}_{16: 0}\right)$,
$8.86 \%$ linoleic acid $\left(\mathrm{C}_{18: 2}\right), 10.85 \%$ linolenic acid $\left(\mathrm{C}_{18: 3}\right), 10.15 \%$ eicosapentaenoic acid $\left(\mathrm{C}_{20: 5}\right)$ and16.93 \% oleic acid $\left(\mathrm{C}_{18: 2}\right), 10.85 \%$ linolenic acid (C18:3), palmitic acid $\left(\mathrm{C}_{16: 0}\right), 8.86 \%$ linoleic acid $\left(\mathrm{C}_{18: 2}\right), 10.85 \%$ linolenic acid $\left(\mathrm{C}_{18: 3}\right)$, $10.15 \%$ eicosapentaenoic acid $\left(\mathrm{C}_{20: 5}\right)$ and $16.93 \%$ oleic acid $\left(\mathrm{C}_{18: 1}\right)$. Sastri ${ }^{10}$ reported $19.7 \% \mathrm{C}_{18}, 15.2 \% \mathrm{C}_{20}$ and $17.1 \% \mathrm{C}_{22}$ of total unsaturated fatty acid in shark liver oil.

Table II. Fatty acid composition of Anchovy body oil (oil content $0.51 \%$ w/w $\mathbf{w}^{5}$ )

\begin{tabular}{|c|c|c|c|c|c|c|}
\hline \multirow[t]{4}{*}{ Name of the fatty acid } & \multirow{4}{*}{ Peak area } & \multicolumn{5}{|c|}{ Fatty acid (FA) \% } \\
\hline & & \multirow{3}{*}{$\begin{array}{c}\text { Saturated } \\
\text { FA } \\
\text { (SFA) }\end{array}$} & \multicolumn{3}{|c|}{ Unsaturated fatty acid (UFA) } & \multirow{3}{*}{ Unknown } \\
\hline & & & \multirow{2}{*}{$\begin{array}{c}\text { Mono } \\
\text { UFA }\end{array}$} & \multicolumn{2}{|c|}{ Poly UFA (PUFA) } & \\
\hline & & & & $\omega-3$ PUFA & $\omega-6$ PUFA & \\
\hline Caprylic $\left(\mathrm{C}_{8: 0}\right)$ & - & - & - & - & - & - \\
\hline Capric $\left(\mathrm{C}_{10: 0}\right)$ & 1004 & 0.11 & - & - & - & - \\
\hline Lauric $\left(\mathrm{C}_{12: 0}\right)$ & 7850 & 0.89 & - & - & - & - \\
\hline Myristic $\left(\mathrm{C}_{14: 0}\right)$ & 46327 & 5.26 & - & - & - & - \\
\hline Myristoleic $\left(\mathrm{C}_{14: 1}\right)$ & 5946 & - & 0.68 & - & - & - \\
\hline Palmitic $\left(\mathrm{C}_{16: 0}\right)$ & 280920 & 31.92 & - & - & - & - \\
\hline Palmitoleic $\left(\mathrm{C}_{16: 1}\right)$ & 97094 & - & 11.03 & - & - & - \\
\hline Stearic $\left(\mathrm{C}_{18: 0}\right)$ & 62451 & 7.10 & - & - & - & - \\
\hline Oleic $\left(\mathrm{C}_{18: 1}\right)$ & 258460 & - & 29.36 & - & - & - \\
\hline Linoleic $\left(\mathrm{C}_{18: 2 \omega 6}\right)$ & 36298 & - & - & - & 4.12 & - \\
\hline Linolenic $\left(\mathrm{C}_{18: 3 \omega 3}\right)$ & 14870 & - & - & 1.69 & - & - \\
\hline Arachidonic $\left(\mathrm{C}_{20: 4 \omega 6}\right)$ & 46815 & - & - & - & 5.32 & - \\
\hline Eicosapentaenoic $\left(\mathrm{C}_{20: 5 \omega 3}\right)$ & 17243 & - & - & 1.96 & - & - \\
\hline Docosapentaenoic $\left(\mathrm{C}_{22: 5 \omega 6}\right)$ & 4911 & - & - & - & 0.56 & - \\
\hline \multirow[t]{4}{*}{ Total } & 880189 & 45.28 & 41.07 & 3.65 & 10.00 & 0.00 \\
\hline & & & & \multicolumn{2}{|c|}{13.65} & \\
\hline & & & \multicolumn{3}{|c|}{54.72} & \\
\hline & & \multicolumn{5}{|c|}{100.00} \\
\hline \multicolumn{2}{|l|}{$\omega-3 / \omega-6=0.37$} & $\mathrm{~A} / \mathrm{SFA}=0$ & & \multicolumn{2}{|c|}{$\mathrm{UFA} / \mathrm{SFA}=1.21$} & \\
\hline
\end{tabular}


In Eel (C. talabonoides), these fatty acids were palmitic (32.04\%), oleic (14.78\%), stearic (11.75 \%), myristic (5.77 \%), linolenic (8.98 \%) and arachidonic (3.12\%) acids (Table III). These results were closing proximate to those of others. ${ }^{9}$ Chowdhury et. $a l^{4}$ found 6.27 to $10.71 \%$ myristic acid, $16.78 \%$ to $28.83 \%$ palmitic acid, $5.95 \%$ to
$22.47 \%$ palmitoleic acid, 7.96 to $22.70 \%$ stearic acid, $7.66 \%$ to $16.93 \%$ oleic acid, $8.53 \%$ to $8.86 \%$ linoleic acid, $9.40 \%$ to $10.85 \%$ linolenic acid, trace to $6.43 \%$ arachidonic acid and 5.59 to $10.15 \%$ eicosapentaenoic acid in shark liver oil, hilsa body oil and mullet body oil.

Table III. Fatty acid composition of Eel body oil (oil content $9.56 \%$ w/w $\mathbf{w}^{5}$ )

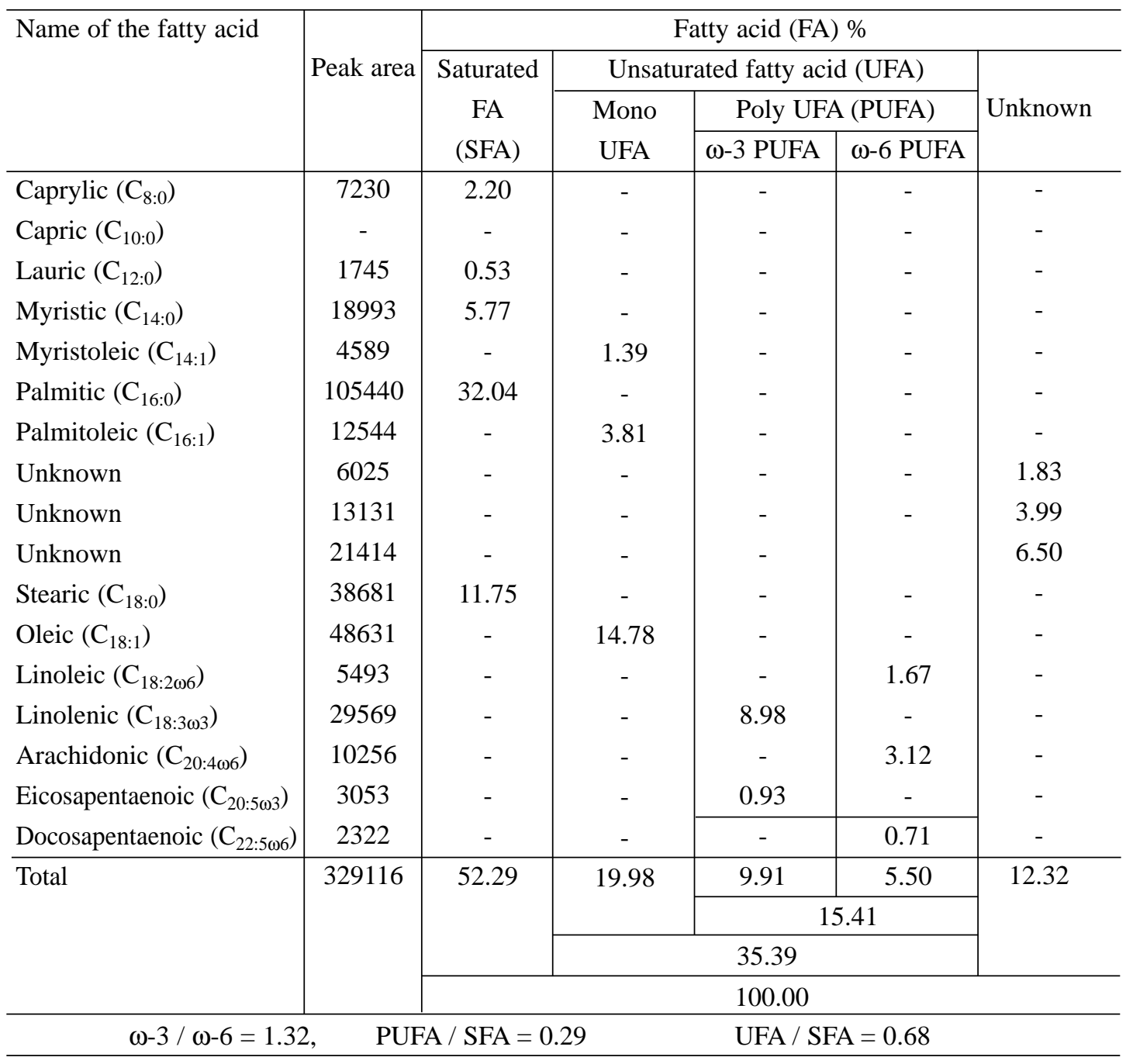


Fatty acid compositions of these three oil samples (Table I, II and III) were almost similar with slight exception. Among the saturated fatty acid, caprylic acid (2.20 \%) was found only in Eel whereas capric acid was higher in Sting Ray (3.24 \%) than other two species (0-0.11\%). Other saturated fatty acid lauric acid (0-0.89\%), myristic acid (4338 - $5.74 \%$ ), palmitic acid (31.92 \% - $35.61 \%)$ and stearic acid (7.10 \% - $11.75 \%)$ were more or less constant. Among the monounsaturated fatty acid, palmitoleic acid (3.81 \%) and oleic acid (14.78 \%) were lower in Eel than other two species (9.10 -11.03 \% and $24.71 \%$ - $29.36 \%$ respectively). Myristoleic acid was more or less constant $(0.68-2.10 \%)$ In case of $\omega$-3 poly unsaturated fatty acids, Linolenic acid level (8.98\%) was much higher in Eel than other two fishes (1.69 - $2.46 \%)$ whereas eicosapentaenoic acid (0.93 \% - $2.12 \%$ was steady in the three fishes. In case of $\omega-6$ polyunsaturated fatty acid, linoleic was higher in anchovy ( $4.12 \%$ ) than other two species (1.23 - $1.67 \%)$ whereas arachidonic acid (2.25 - $5.32 \%)$ and docosapentaenoic acid (0 - $0.71 \%$ ) were somewhat steady throughout the investigation. The variation of fatty acid composition may be due to the variation of feeding habits and environmental conditions. ${ }^{4,7}$

Some investigators researched on different marine fishes. Andrade et al. ${ }^{11}$ found $3.06 \%$ Myristic acid in Brazilian Anchovy. Jeong et al. ${ }^{12}$ found $16.30 \%$ palmitic acid, $3.69 \%$ palmitoleic acid, $9.76 \%$ stearic acid, $9.27 \%$ oleic acid in Electric Ray (Narke Japonica); $5.78 \%$ myristic acid, $18.84 \%$ palmitic acid, $5.89 \%$ palmitoleic acid, $5.28 \%$ oleic acid in anchovy (Engraulisjaponica); and $4.45 \%$ myristic acid, $18.56 \%$ palmitic acid, $7.98 \%$ palmitoleic acid, $28.80 \%$ oleic acid in Sea Eel (Astroconger myreaster). Slightly values were observed with the present studies due to the variation of species, feeding habits, temperature, spawning conditions etc. ${ }^{4,7}$

Sting Ray liver oil (Table I) and Eel body muscle opl (Table II) contained more saturated fatty acid (52.95\% and $52.29 \%$ ) than unsaturated acid whereas anchovy body muscle oil contained more unsaturated fatty acid (54.72 \%) than saturated fatty acid (Table II). Sastri ${ }^{10}$ reported $60 \%$ unsaturated fatty acid in Indian shark liver oil and $63 \%$ unsaturated fatty acid in fresh water hilsa body oil. Yusuf et al. ${ }^{9}$ studied on twelve marine species of the Bay of Bengal and found 38 to $59 \%$ saturated fatty acids 8.9 to $35 \% \omega-3$ fatty acid and 2.5 to $9.2 \% \omega-6$ fatty acid. He also found $54 \%$ unsaturated fatty acid in fresh water hilsa oil. Andrade et al. ${ }^{11}$ found $21.19 \% \omega-3$ fatty acid in Brazilian Anchovy fish. Chowdhury et. at. ${ }^{4}$ found 37.46 - 6224 \% saturated, 37.76 - $62.54 \%$ unsaturated, 14.89 - $21.00 \% \omega-3$ polyunsaturated and $8.53-15.21 \% \omega-6$ polyunsaturated fatty acid in three marine fishes. These results are correlated to the result of present study. $\omega-3$ fatty acid value was found higher in Eel 
(9.91 \%) (Table III) than Sting Ray (4.58 \%) (Table I) and Anchovy (3.6 \%) (Table II) oils. Total $\omega-6$ fatty acid (10.00 \%) in Anchovy (Table II) was much higher than those of other two fishes (Tables I and III). This was due to the higher arachidonic acid and linoleic acid in Anchovy (Table II). The present finding is co-related to those of other researchers. ${ }^{8,9}$ The ratio of $\omega-6$ series of fatty acids in Eel oil (1.80) was higher than Anchovy oil (0.37 \%) and Sting Ray (1.32).

Many reports showed beneficial dietary effects ${ }^{13}$ and lower incidence of cardiovascular problem upon ingestion of the fish oil were due to the presence of $\omega$-3 series of fatty acid. ${ }^{14,15}$ The four pairs of fatty acid namely $\mathrm{C}_{14: 0}+\mathrm{C}_{18: 0}, \mathrm{C}_{16: 1}+\mathrm{C}_{18: 1}, \mathrm{C}_{20: 1}, \mathrm{C}_{22: 5 \mathrm{w} 3}+$ $\mathrm{C}_{22: 6 w 3}$ in fish oil determine the valuable properties of the oil. ${ }^{9}$ From the present study of fatty acid composition of these fish oils showed a beneficial effect on nutritional and commercial purposes.

\section{References}

1. M. Zafar and N. Mahmood. Occurrence and abundance of penaeid postlarvae of the Genera Penaeus, Metapenaeus and Parapenaeopsis in the estuarine water of Satkhira. Bangladesh.Chittagong Univ. Stud. Part II: Science, 18(1) (1994) 39-45.

2. M. A. Huq, A. A. Sirajee, M. B. Chowdhury, K. K. Nath, P. Seal and H. R. Bhuiyan. Studies on the lipids in three commercial fishes the Bay of Bengal, Bangladesh J. Sci. Ind. Res. 34(3-4) (1999) 318-323.

3. A. K. M. Nuruzzaman. Bangladesh country paper on Fisheries Socio-economics and marketing. Dhaka, BARC (16-17 Nov. 1993) 1-10.

4. M. B. Chowdhury, A. A. Sirajee, H. R. Bhuiyan, M. A. Huq, K. M. Ismail. Studies on fatty acid profile of three commercial fishes of the Bay of Bengal, Bangladesh $J$. Sci. Ind. Res. 38(1-2) (2003) 49-54.

5. H. R. Bhuiyan, M. B. Chowdhury, K. K. Nath, P. Seal and Ezharul Hossain, Nutritional studies on three marine eishes the Bay of Bengal, Bangladesh J. Sci. Ind. Res. 39(1-2) (2004) 101-106.

6. M. A. Huq, K. K. Nath, H. R. Bhuiyan, A. A. Sirajee and M. Ahmed. Seasonal variation in the biochemical composition of three shell fishes in the South-East coast of Bangladesh, Bangladesh J. Fish. 23(1) (2000) 17-24.

7. G. Lambertsen. Fatty acid composition of fish fats, comparisons based on eight fatty acids, Fsk, Dir. Dkr. Ser. Eruaring. 1 (1978) 105-116.

8. S. S. Jahan. Investigation of the changes of biochemical Components of hilsha fish (T. ilisha) under different storage conditions, PhD. Thesis, Dhaka University. (1993) 190. 
9. H. K. M. Yusuf. S. R. Alam, R. Rahman and S. Quazi. Fatty acid in twelve marine fish cpecies of the Bay of Bengal, J. of Food Composition and Analysis, 6(4) (1993) 346-353.

10. B. N. Sastri. The Wealth of India, raw materials in fish and fisheries, published by CSIR (New Delhi), 4 (1962) 102-113.

11. A. D. Andrade, J. V. Visentainer, M. Matsushita and N. E. Souza. Omega-3 fatty acid in backed marine fish from South of Brazil, Arq. Biol. Technol., 39(1) (1996) 187-192.

12. B. Y. Jeong, B. D. Choi, S. K. Moon, J. S. Lee. Fatty acid composition of 72 species of Korean fish,, J. Fis. Sci. Tech., 1(1) (1998) 129-146.
13. Pozo and S. D. Nogre. Total lipids and omega-3 fatty acid from seven species of Pelagic dish, the resource and the exploitation, Fishing news books, Scotland, (1992) 142-147.

14. H. N. Bang and K. Green. Methods for production of fish liver oil from liver of low oil content, Fisheries Research Board, Can, Progr, Rept, Bull., 22 (1971) 18.

15. H. R. Bhuiyan, M. B. Chowdhure, K. K. Nath, P. Seal and M. A. Huq. Studies on the biochemical parameters of cynoglossids in the Kutubdia Channel, Bangladesh. Bangladesh J. Sci. Ind. Res. 38(1-2) (2003) 91-96. 